\title{
建築生産情報の計画的確定手法の開発と GA の適用可能性 \\ DEVELOPMENT OF STRATEGIC DECISION MAKING SYSTEM \\ OF BUILDING DETAIL DESIGN AND EXPLORING \\ A SCHEDULING SYSTEM ON GENETIC ALGORITHM
}

\author{
峰政克義，伊藤 健 司**, 古阪秀三*** \\ Katsuyoshi MINEMASA, Kenji ITO and Shuzo FURUSAKA
}

\begin{abstract}
Contractors and suppliers make shop drawings to start construction and parts production.. Approving those shop drawings by architects and clients is just decision making process of detail design during construction process. The approval of shop drawings tend to be delayed because of a client and architects' endless re-examination of design. If almost of all shop drawings decided in advance actual limits at several stages, construction cost and term would be stably controlled.

In this paper we want to clarify above process, and develop a schedule planning system which timely offers clients and architects coherent shop drawings to stimulate them to make decision easily at early stage. Therefor we explore the scheduling system on genetic algorithm to find optimum solution both clients-architects side and contractors-suppliers side.
\end{abstract}

Keywords : shop drawings, decision making of detail design, collaborative working system, genetic algorithm, scheduling system, 生産情報、生産情報確定工程、同時並行検討、遺伝的アルゴリズム、生産情報確定工程作成システム

1.はじめに

1. 1 背景

設計内容の詳細部分は、生産段階において、施工図や製作戍など の生産情報として確定される。確定時期の遅延は後続の現場工程の 不安定要因となるため、生産担当者泿1) は可能な限り早期に決めら れるよう、多くの努力を払ってきた。その過程は、詳絴部分の検討 先続行する発注者や設計者の合意を得て、多種多様な作成者による 施工図や製作図を生産工程にあわせて確定していくものである。そ して、生産情報を可能な限り早期に確定することによって、発注者 の工程短縮への要求に応えることとともに、工事コス卜の抑制を図 ってきた。しかし、それらの工夫は作業所長の個人的ノウハウとし て蓄積され、建設産業としての標準化はなされてこなかった。

\section{2 本論文の目的}

本論文では、工事費の抑制、工期の短縮などを可能にするために、 生産情報の計画的早期確定を支援する工程表の作成手法を提案する。

具体的には、同時並行検討される生産情報が多段階で確定される 性質を利用した情報群の前倒しによる計画的早期確定手法とその最 適解注2)を GA (Genetic Algorithm, 遺伝的アルゴリズム)によって 求める手法を提案与る。

\section{3 本論文の概要}

本論文は、生産現場の作業所長が担当するプロジェクトに最適な 生産情報確定工程を作成するための手法の構築を目指すもので、具 体的には下記の内容を含む。

・生産情報の確定過程の詳細な分析から、その構造を明らかにし、 生産情報確定工程のモデル化に活用寸る。

・生産情報の計画的早期確定への動機、そのための仕事量の増加と 早期化に対する抵抗要因を、経験豊富な実務者のヒアリングによっ て明らかにし、生産情報確定工程作成に活用寸る。

・以上を基に GA 手法を使って最適解を求める方法を提案する。

\section{2. 生産情報の計画的早期確定の要件 \\ 2. 1 生産情報確定の基本的な要件}

生産情報の確定順序は生産工期からの逆算と発注者や設計者が確 定しやすい順序とを勘案して決まる。その要点は下記のとおり。

1）生産情報の相互関係の特定

生産情報の相互の関係としては、(1)特定の情報に基づいて後続の 情報が確定する先行・後続の関係、(2)デザイン上の調和や設置場所 の近接、機能上のつながりにより、同時並行検討し整合を図るべき
* 財闷法人住宅総合研究財団 軎務理事

** 清水建設株式会社情報システムセンター 主桿

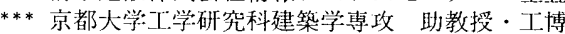

Senior Managing Director, JYUSOKEN (Housing Research Foundation) Chief Engineer, Information Systems Center, Shimizu Corporation

Assoc. Prof., Dept. of Architecture and Architectural Systems, Kyoto University, Dr. Eng. 


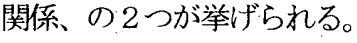

生産情報の先行・後続および同時並行 検討の関係を各図面ごとに経験豊富な実 務者のヒアリングを基に取りまとめたも のを表 1 に示す。当該情報より早く確定 すべき先行情報（A）、当該情報と同時に 検討す心゙き同時並行検討情報（B）、後続 して決めるべき情報（C）を、情報の内 容ごとに記載したものである。それを基 に、ISM (Interpretive Structural Modeling)お よび DEMATEL(Decision Making and Evaluation Laboratory)分析を行い、情報全 体の先行・後続と同時並行検討の関係を 表わしたものを図 1 に示す。

\section{2）生産情報確定工程の詳細}

生産情報の確定過程で設計者が行う作 業は「設計内容の詳細な検討」とそれに 基づいて、施工者からの生産情報を「検 討・承認」することであり、主施工者が 行うべき作業は生産情報の「作成」と各 専門技術別施工者や部品製造者が作成し たものの「整合チェック」である。その 過程は、図 2 に示寸ように、設計者、主 施工者の閒で、数度にわたるチェック、 検討、打ち合わせ、作図修正の後、設計 者の検討・承認が行なわれ情報が確定す る。

しかし、実際の生産情報の確定工程で は、煩雑を避けるため、設計者の検討に 入るまでを主施工者の整合チェックも含 めて「作図」とし、検討開始以後を設計 者による詳細な検討も含めて「㭘討・我 認」とみなしている。そして、それぞれ の中に、不確定要素を持つ打ち合わせ時 間、待ち時間が含めで表現される。この 不確定要素および作業の短縮可能な部分がフロートを構成する。

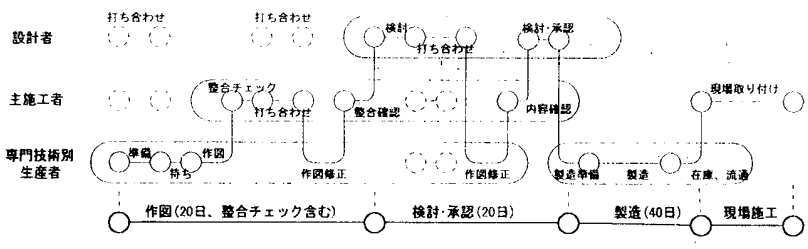

图 2 単位工程の詳紏（アルミサッシ摽準品の工程例）

\section{2 生産情報の早期確定への動機とその要件}

生産情報を早期に確定することができれば、時間的に余裕を持っ て最適の製造担当者や工法の選択が可能になり、コス卜抑制などの 可能性を生むと同時に、【期短縮の要望に合理的に态えることがで きる。また、生産途上の不測の事態にあっても時間的余裕により、 計画外の工事コス卜増の防止に役立つことが期待される。

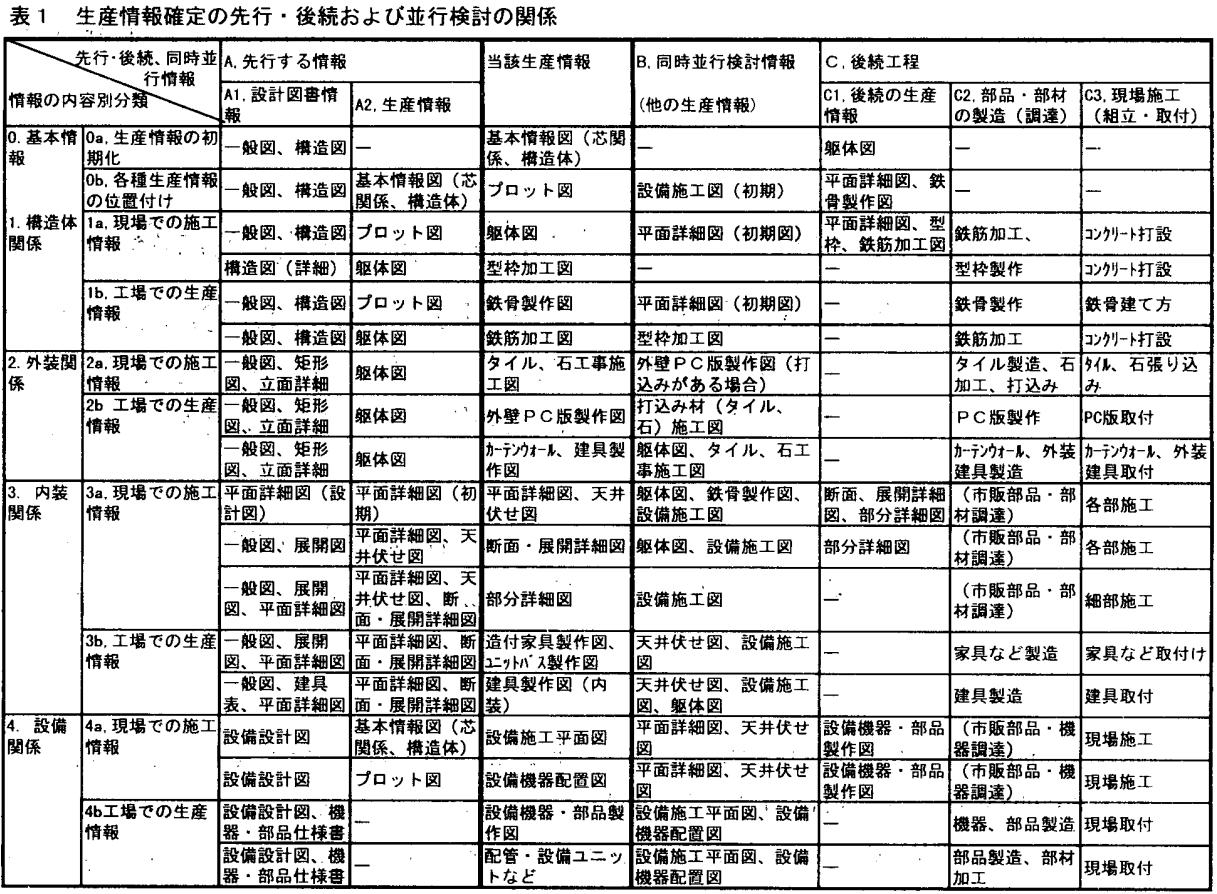

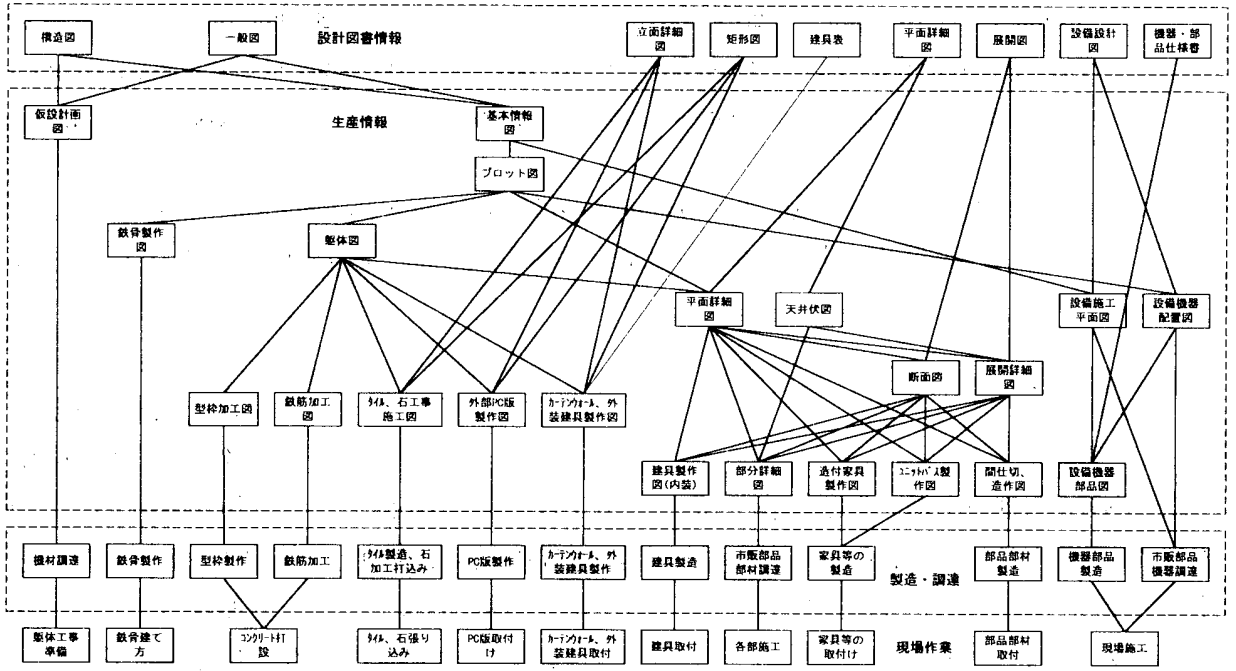

図 1 ISM, DEMATELLによる先行・後続、同時並行検討関係の確認

これらは、工事費の抑制、工期の安定化で最終的には発注者の利 益に繋がるものである。

次ページの表 2 は高層集合住宅の事例に基づき、早期確定に期待 される効果を各生産情報別に記述したものである。この事例では、 早期確定により、生産情報確定コス卜の削减も含めて工事費はおよ そ $8.5 \%$ 程度の削減が可能と考えられる。

\section{1）早期確定による工事費の抑制}

早期確定により、主施工者にとってはコストネゴシエーション の時間の確保、早期確定による技術検討、最適工程の選択、などが 可能となるため、コス卜抑制の可能性が拡大する。

各専門技術別施工者にとっては、生産情報の早期確定により、 最適の時期を選んで、低コストの労務、資材の調達、部品・部材の 製造をすることが可能になる。

コスト削減の可能性が大きいものとしては、部品製造、設備工 事関係に関するものが举げられる。 
表2 生産情報別の早期確定に見込まれる効果

\begin{tabular}{|c|c|c|c|c|c|c|c|c|c|c|}
\hline \multirow{2}{*}{\multicolumn{2}{|c|}{ 生産情却因種放 }} & \multirow[t]{2}{*}{ 工車費(\%) } & \multicolumn{3}{|c|}{ 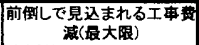 } & \multicolumn{2}{|c|}{ 生應情報作成费 } & \multicolumn{3}{|c|}{ 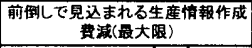 } \\
\hline & & & 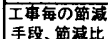 & & 工事费 & 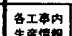 & & & 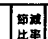 & \\
\hline 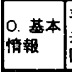 & 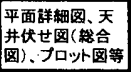 & & 他果) & 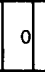 & & & & 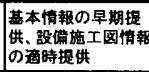 & 20 & \\
\hline \multirow[t]{2}{*}{ 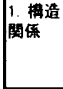 } & 怔体图 & 型格 & 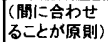 & 0 & & 4 & & - & 0 & \\
\hline & 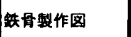 & 14 & 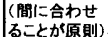 & 이 & 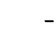 & 2 & 0.28 & - & 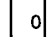 & \\
\hline \multirow[t]{3}{*}{ 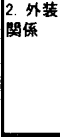 } & 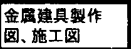 & 6 & 早期磷定 & 10 & 0.6 & 3 & 0.18 & 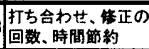 & 25 & \\
\hline & 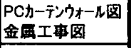 & 4 PC版 & 早期硪定 & 10 & 0.4 & 3 & 0.12 & 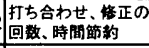 & 25 & 0.0 \\
\hline & 石・タイル施工图 & & 早期碹定 & 10 & 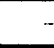 & 5 & & 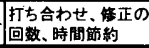 & 25 & \\
\hline \multirow[t]{4}{*}{ 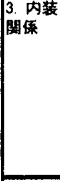 } & 木工事施工图 & & 早期磪定 & 10 & 0.7 & 6 & 0.42 & 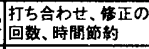 & 25 & 0.1 \\
\hline & 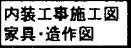 & 4 & 早期磪定 & 20 & 0.8 & 2 & 0.08 & 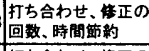 & 25 & 0.02 \\
\hline & 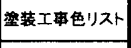 & & 早期確定 & 0 & & 0 & & 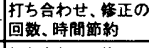 & 10 & \\
\hline & 2ニ朴ベス慗作图 & & 早期磪定 & 10 & 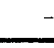 & 4 & & 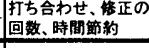 & 10 & \\
\hline \multirow[t]{2}{*}{ 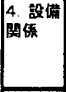 } & 設绡施工图 & 16 & 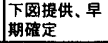 & 30 & 5 & 10 & 1.6 & 下图作成手周の削的 & 50 & 0.8 \\
\hline & 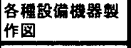 & 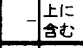 & 早期磪定 & 20 & 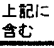 & & & 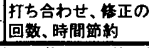 & & 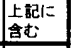 \\
\hline 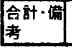 & & 54 & 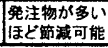 & & & 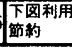 & & & & 0.93 \\
\hline
\end{tabular}

2）早期確定による生産情報確定コストの抑制

複数の情報を前倒しして同時並行検討し、確定するために、個 別に確定する場合に比べ、主施工者にとっては情報を参照、照合す る時間と手間が省ける。また、先行する情報の早期確定により、後 続の生産情報の作成、確定が確実に行なわれるようになり、先行情 報の不確実な状態に起因する手戻りなどの手間が減る。

具体的には、施工図や製作図の下図として活用可能な基図の早 期提供などにより、平面図系の図面が多いものほど手間の削減が可 能で、表 2 に見られるように前項と同様に部品製造、設備工事関係 に関するものに与える影響が大きい。

3）工期の安定化

(1)予め発注者、設計者と合意することにより工期が安定すること、 (2)各段階の工程上重要な情報が確実に確定されること、(3)各情報 の確定以後の工程それぞれにフロートを確保できること、などによ り生産途上における不測の工事費増加や工期遅延を回避できる可能 性をもたらす。

\section{4）計画的早期確定の範囲と効果}

生産情報確定の計画的早期化の程度は、前項の阻害要因解消を どこまで行うことができるかに依存する。

その範囲は、(1)各段階ごとの情報をその段階内で前倒しするこ とから、(2)発注者や設計者の合意を得て、それぞれの段階の情報を 群ごと前倒しして、大幅な早期確定化を図ること、まで可能であり、 得られる効果はその前倒しの程度による。

\section{a . 段階内での前倒しの場合}

各段階の情報確定の前提となる情報を基に、相互の先行・後続、 同時並行検討の関係を維持しながら、各情報それぞれのフロートを 活用した確定工程の前倒しを行うことができる。この場合の予想さ れる効果は、一般的に表 2 に示寸 $8.5 \%$ のちの 3 分の 1 程度が見 込まれる。

\section{b ．複数の段階の情報をまとめて前倒し確定する場合}

複数の確定段階をまとめて前倒しすることも、発注者や設計者の 合意が得られれば可能となる。発注者や設計者が大幅な意思決定の 前倒しに合意しやすい機会やイベントが提案され合意される必要が
ある。通常、構造体関係、外装材関係の段階にその後の内装関係の 段階の情報をまとめて前倒しして確定することが行なわれる。前述、 8.5\%の効果はこの前倒しにより想定されるものである。

\section{3. 新しい生産情報確定工程のしくみ}

すでに一部の建設会社で活用されている生産情報確定工程の工. 程表の多くは、主として現場の作業工程を制約条件として、生産情 報の作成に関する工程表を作成するものであり、各生産工程相互の 調整を行いながら、工程全体を改善寸るような機能を有してはいな い。ここでは、前章で明らかにした、生産情報確定の順序と計画的 に早期確定する要件を基に、生産情報確定工程を構築するルールや 制約条件を設定し、新しい生産情報確定工程のしくみを考える。

\section{1 生産情報確定工程を構築するルール}

生産情報の確定順序は確定工程を作る上での基本的なルールとな る。前章で述べた要件を従来からの生産情報確定工程の作成システ ムに組み込むべきルールとして設定する。

\section{1）生産情報確定工程を構成する基本的なルール \\ a . 生産情報相互の関保による制約}

生産情報の確定順序に関する制約は、先行 ・後続と同時並行検討 の関係である。

先行・後続の関係による工程構成上の制約を図 3 に示す。後続の 情報の検討・承認は、先行する情報の確定後でないと着手できない。

また、同時並行検討による工程構成上の制約は図4 に示すように、 検討承認期閒が重なることが必要である。
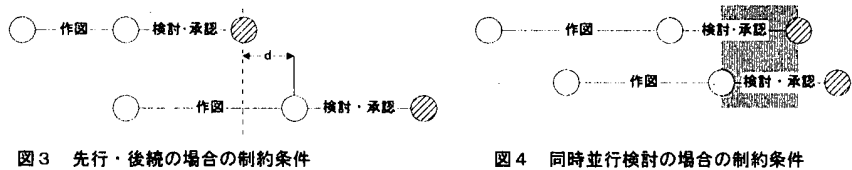

\section{b ．フロートを活用して工期短縮を行うルール}

ここでは、2 章で述べた要件を基に、工程上のフロートを、費用 の増加を伴わないで短縮可能な explicit フロートと、労務の追加投 入などのために工事費の増加を伴 うimplicitフロートに分けて考える。 図 5 に示すように、通常の工程短

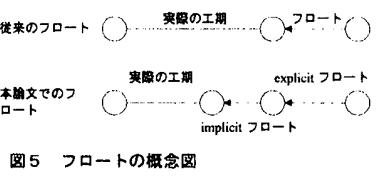
縮にあたっては explicitフロートを、大幅な短縮にあたっては implicit フロートをも使い、圧縮の程度によっては大幅な工事費増を伴うと 考える。

\section{2）多段階確定のルール}

筆者らは、すでに、生産情報は同時並行検討する情報ごとにいく つかの段階でまとまって確定されること、具体的には検討・承認さ れる過程で、構造関係の情報、外装関係の情報、内装関係の情報、 毎にまとまりがみられ、それらが順序を追って確定していく多段階 の確定過程を構成すること、を明らかにしている。1)

\section{a . 確定段階の設定ルール}

生産担当者は、確定の段階分けを発注者や設計者の意思決定過程に そった形で、しかも可能な限り少ない段階で早期にまとめるよう工 夫する。一般的にそれらは、基本情報の確定段階、構造関係情報の 確定段階、外装関係情報の確定段階、内装関係情報の確定段階、設 
備関係情報の確定段階に分けられる。実際の工程では、外装が工業 化部品による場合、構造と外装関倸が重なり、構造・外装関係確定 段階となり、内装関係结部品製造に関するものと、現場施工に関す るもので確定すべき時期をずらすことが可能で、分割される傾向に

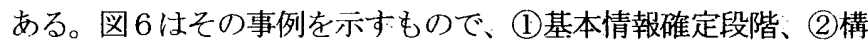
造·外装関係情報確定段階、(3)内装 (部品製造) 関係情報確定段階、 (4)内装(現場施工) 関係情報確定段階の 4 段階に分けている。

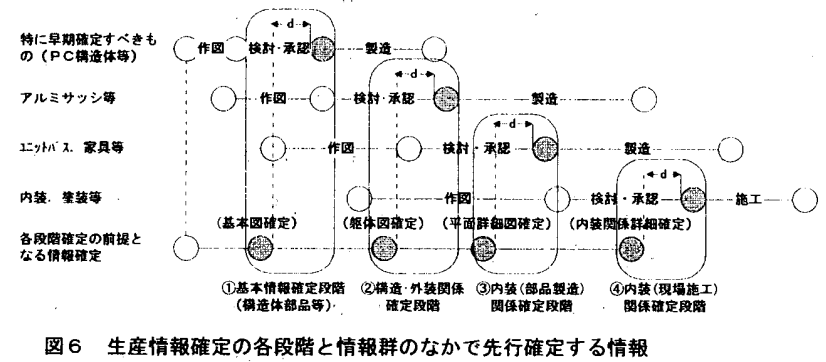

b. 各段階の確定を先導する情報

それぞれの段階においては、その段階の情報の基本となる生産情 報が先行して作成、検討、確定され、それが当該段階のその他の情 報確定の前提となる。

構造関係情報の確定にあたっては芯関係などの基本情報や主な 設備の配置を示すプロット図などの情報、外装関係情報の確定にあ たっては躯体図などの情報、さらに、内装関係情報の確定にあたつ ては平面詳細図に示される内装に関する基本的な内容の情報、が先 行して確定する。図6に示すように、各段階の情報に先行して確定 されるべき情報の確定時期を超えた前倒し確定はできない。したが って、図のモデルで示すように、ず゙てのd 証の值をとる。

\section{2 計画的早期確定の制約条件}

生産情報の計画的早期確定を検討する上で、発注者・設計者に 起因寸る阻害要因解消のための手間やコストの増大、作業の集中、 作業の早期開始への圧力などが制約条件となる。早期化の程度は 2 . 2 項で述べた期待される利益とのバランスで決まる。

\section{1) 発注者、設計者による早期確定阻害要因への対応}

早期確定を阻害する要因としては、詳細な設計内容の未定部分に つて発注者や設計者による意思決定が残っていること、その確定 にあたって生産担当者の技術に基づいて実現される内容を参照して 確定したいこと、実現内容を現場で現物で確認したいこと、さらに 確定対象の特定の生産情報の夕でなく関連する生産情報とあわせて 常に全体像を確認しながら決定したいこと、などが挙げられる。こ れらの阻害要因への対応を考え、生産情報の計画的早期確定の制約 条件を明らかにする。

\section{a . 設計詳細内容の検討続行への対応}

生産情報の計画的早期確定には、作成から検討・承認の工程まで の工程表を作成し、生産情報確定期限に間に合うように、詳細な設 計内容の決定について、予如合意しておくことが前提となる。実際 に採用する技術や内容を施工図や製作図て確認可能と寸るため、各 生産担当者は保有する技術に基づき、施工法、実現する内容の詳細 を記載した生産情報を提案し、設計内容の確定を促進する。生産情 報確定工程の制約条件としては、生産情報確定早期化のための活用 可能なフロートの量、および専門技術別施工者や部品製造者の早期 決定の限界が挙げられる。

\section{b．現場、現物での確認志向への対応}

発注者、設計者ともに、設計意図・デザインの細部を実際の建 物で確認しようとする傾向がある。この傾向への対策として、実大 模型、部分兒本を作成し、出来上がりの姿に代え、確定する方法が とられ、発注者や設計者の早期意思決定の支援手段として活用され る場合が多い。実大見本や実物の部分模型などを作成、提供するた めの費用は当該部分の実際の工事費の数パーセント程度と考えられ、 多額に及ぶ場合は追加の費用が認められる場合が多い。

これらの方法は段階ごとの前倒しに大幅な早期確定が期待され る場合に採用される。実施に伴う費用と時間は少なくはないが、そ れを見込んでも、前述のとおり早期確定の利益は大きいと考えられ ている。なお、たとえば模型作成用の図面の作成、検討·承認は製 作図などの検討過程で行なわれるため、作業の集中を考慮する必要 があり、それが制約条件となる。

\section{c. 全体像確諗志向への対応}

発注者や設計者は特定の生産情報を検討・承認する場合において も、それらに関する情報を一覧し、常に全体像を確認する志向を持 ro

現在、全体像における特定の生産情報の位置づけを確認するため に、平面系の基本的な情報を記載する「総合図」が作成されるよう になってきている ${ }^{2)}$ が、同時に、関連する情報との関係を確認す るための情報の取り揃え、整合チェックが必要となり、そのための 手間の増大と集中も制約条件となる。前出の図6に示すように生産 情報の確定を各段階で同時並行検討寸べき群ごとに確定していくこ とで対応可能となる。

2）生産情報の作成、照合チェックおよび検討・承認の工程能力上 の制約

生産情報の計画的早期確定のために注、そのための作成、整合 チェックおよび検討・承認作業の早期集中が生じる。ここでは、こ れに対応する能力を工程能力という。早期確定を支障なく行うため の工程能力の確認は、同時期に集中寸る作図およひ整合確認作業の 総量と、活用可能な担当者の工程能力を比較寸ることによって行な われる。工程能力が不足する場合、それが工期短縮の限界であり、 不足工数を調達寸れば割増コス卜が必要となる。いずれにせよ、こ れらが制約条件となる。

生産情報作成に要する工数、整合チェックに要する工数、設計者 が検討承認に要する工数を実態の分析から推定したものを表 3 に示 す。表中、専門技術別施工者や部品製造者が作成する図面のうち、 専ら自らの作業のための図面を除いたものが、主施工者の整合チェ ック、およひ設計者の検討・承認の対象となる。また、主施工者の 整合チェックの工程は前出の図 2 に示すように、各生産情報の作成 工程の後半部分に含めて考える。

生産情報確定を早期化する場合、二つの作業集中が発生する。そ の一つは個別の情報の工期を短縮することによる作業の集中であり、 二つ目は複数の生産情報の作成、整合チェック、およひ検討・承認 の作業が重なる場合の作業の集中である。

個別の情報の作業集中をまねく工程短縮は、その工程に含まれる フロートの範井で対応される。主施工者の躯体図・平面詳細図・天 井伏せ凰など早期に作成しなければならないもの、専門技術別施工 者およひ部品製造者の施工図、製作図などで大量に作成しなければ 
表3 生産情報の図面枚数と主施工者の必要実工数の設定

\begin{tabular}{|c|c|c|c|c|c|c|c|c|c|c|}
\hline \multirow{2}{*}{\multicolumn{2}{|c|}{$\overbrace{\text { 生産情報-图枆別 }}^{\text {等担当者の必要工数 }}$}} & \multicolumn{3}{|c|}{ 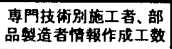 } & \multicolumn{3}{|c|}{$\begin{array}{c}\text { 主施工者による情報作 } \\
\text { 成。エエックの数。 }\end{array}$} & \multicolumn{3}{|c|}{ 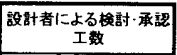 } \\
\hline & & 图面数 & 笨位工 & 乘要 & 洨象魾 & 戦位工 & 必要工 & 对象图 & 学位工 & 必要工 \\
\hline \multirow[t]{5}{*}{ ○. 基本情報 } & 基本情䢁图 & - & $\exists$ & $=$ & -7 & 1.5 & 0 & 20 & 0.5 & 10 \\
\hline & プロット图 & - & - & - & 20 & 1.5 & 30 & 20 & 0.5 & 10 \\
\hline & 平面詳胡图 & - & $\exists$ & - & 100 & 2.0 & 200 & 100 & 0.5 & 50 \\
\hline & 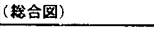 & - & - & $\exists$ & 同上 & 同上 & 同上 & 同上 & 同上 & 同上 \\
\hline & 天井伏世图 & - & - & 二 & 50 & 1.0 & 50 & 50 & 0.5 & 25 \\
\hline \multirow[t]{2}{*}{ t. 整造關係 } & 祭体图 & - & $\exists$ & - & 130 & 1.5 & 195 & 130 & 0.5 & 65 \\
\hline & 铁骨慗作图 & 2000 & 0.5 & 1000 & 150 & 0.2 & 30 & 150 & 0.2 & 30 \\
\hline \multirow[t]{4}{*}{ 2. 外挂関保 } & 金属建具图 & 100 & 1.0 & 100 & 100 & 0.2 & 20 & 100 & 0.2 & 20 \\
\hline & PCカーテンクイール图 & 4000 & 0.5 & 2000 & 150 & 0.2 & 30 & 150 & 0.1 & 15 \\
\hline & 金風工事图 & 350 & 1.0 & 350 & 150 & 0.5 & 75 & 150 & 0.2 & 30 \\
\hline & 五・タイル施工圆 & 15 & 1.0 & 15 & 15 & 1.0 & 15 & 15. & 0.5 & 8 \\
\hline \multirow[t]{5}{*}{ 3. 内装関保 } & 木工薄工図 & - & - & 7 & 平群 & 1.5 & 0 & 平詳 & 0.5 & 0 \\
\hline & 内菱工事施工図 & - & - & - & 200 & 1.0 & 200 & 100 & 0.2 & 50 \\
\hline & 蓺装工事色リ자 & - & - & - & 10 & 1.5 & 15 & 10 & it & 10 \\
\hline & 家具·造作墼作图 & 20 & 1.5 & 30 & 20 & 1.0 & 20 & 20 & 0.5 & 10 \\
\hline & ב朴へ次製作圆 & 20 & 1.0 & 20 & 20 & 0.5 & 10 & 20 & 0.5 & 10 \\
\hline \multirow[t]{3}{*}{ 4. 陪德関係 } & 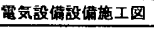 & 150 & 1.0 & 150 & 150 & 0.5 & 75 & 150 & 0.5 & 75 \\
\hline & 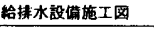 & 200 & 1.0 & 200 & 150 & 0.5 & 75 & 150 & 0.5 & 75 \\
\hline & 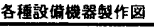 & 50 & 0.5 & 25 & 30 & 0.5 & 15 & 30 & 0.5 & 15) \\
\hline
\end{tabular}

ならないものでは、生産情報の作成作業が集中するため、早期確定 を考える場合、特に工程能力に照らして確認する必要がある。

複数の情報の作図、整合チェックの作業の重複については、主施 工者およひ設計者の生産情報に関わる工程能力が重複の程度を制約 する条件となる。

\section{a . 主施工者の工程能力による制約}

主施工者は図面を作成するとともに、専門技術別施工者によって 作成される図面の整合チェックも行う。したがって、それら2つの 作業の重複に対する工程能力によって、主施工者による工程の前倒 しは制約される。担当者の工程能力の補強可能な範网がその作四お よひ整合チェック作業集中の限界となる。

\section{b．設計者の工程能力による制約}

設計内容の詳細検討作業の集中、生産情報の 検討・承認のための作業の早期集中に対して工 程能力上、刘応可能であるかどうかが問われる。 3）専門技術別施工者、部品製造者决定上の制 約

生産情報の作成、整合チェックなどの作業の 早期集中のほかに、生産者側に起因する阻害要 因として、専門技術別施工者や部品製造者への 発注の遅れによる作図開始時期の決定の遅れが 挙げられる。主施工者の早期決定八の姿勢が制 約条件となる。

\section{4. 生産情報確定工程の作成}

\section{1 新しい生産情報確定工程作成のフロ一}

寸でに開発、利用されてきた一般的な工程計 画作成システムに、3．1 1） b で述心゙た 2 種類のフロートならびに後述のGAによる最適 解の探索を組み込んだ、新しい生産情報確定工 程システムの処理フローを図 7 に示寸。

新しいシステムでは、まず現場の作業工程作 成時に、個々の現場作業に対する explicit フロー 卜を明確化するとともに、労務状況などを考慮 した implicit フロートを定義できるようにしてい る。また、この現場の作業工程に合わせた標準
的な生産情報確定工程作成時に、個々の生産情報確定作業に対して も explicit フロートならびに implicit フロートを定義する。 次に、この 2 種類のフロートを持つ生産情報確定工程を初期工程 として、5章で述べるGAを利用して生産情報確定作業の前倒しお よびフロートの短縮を行い、生産情報確定工程の作業日数やコスト の評価から最適解を求めるものである。

\section{2 新しい確定工程のモデル}

現場の作業工程に 2 種類のフロートを 組み込んで作成した工程表を図 8に示す。 平面詳細図などの基本的な情報が確定す るタイミングで、情報が確定するまとま り（生産情報群）が形成され、先行する 情報群に引き続き後続の情報群が確定し ていく情報確定の仕組みがうかがえる。

この工程は、図 7 に示した新しい生産 情報確定亡程システムの処理Aの結果で ある、「生産情報確定工程を含む工事工程 の提示」に該当するものである。

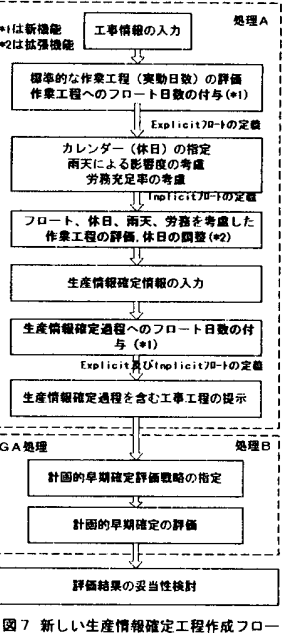

さらに、この工程に、2.24）a 項

で述べた段階内での前倒しを、3．1 項に列記したルール、3. 2項の制約条件を考慮して行ったものを図 9 に示与。これは、次章 のGA分析により、計画的早期確定を行った結果をモデルとして図 化したものである。
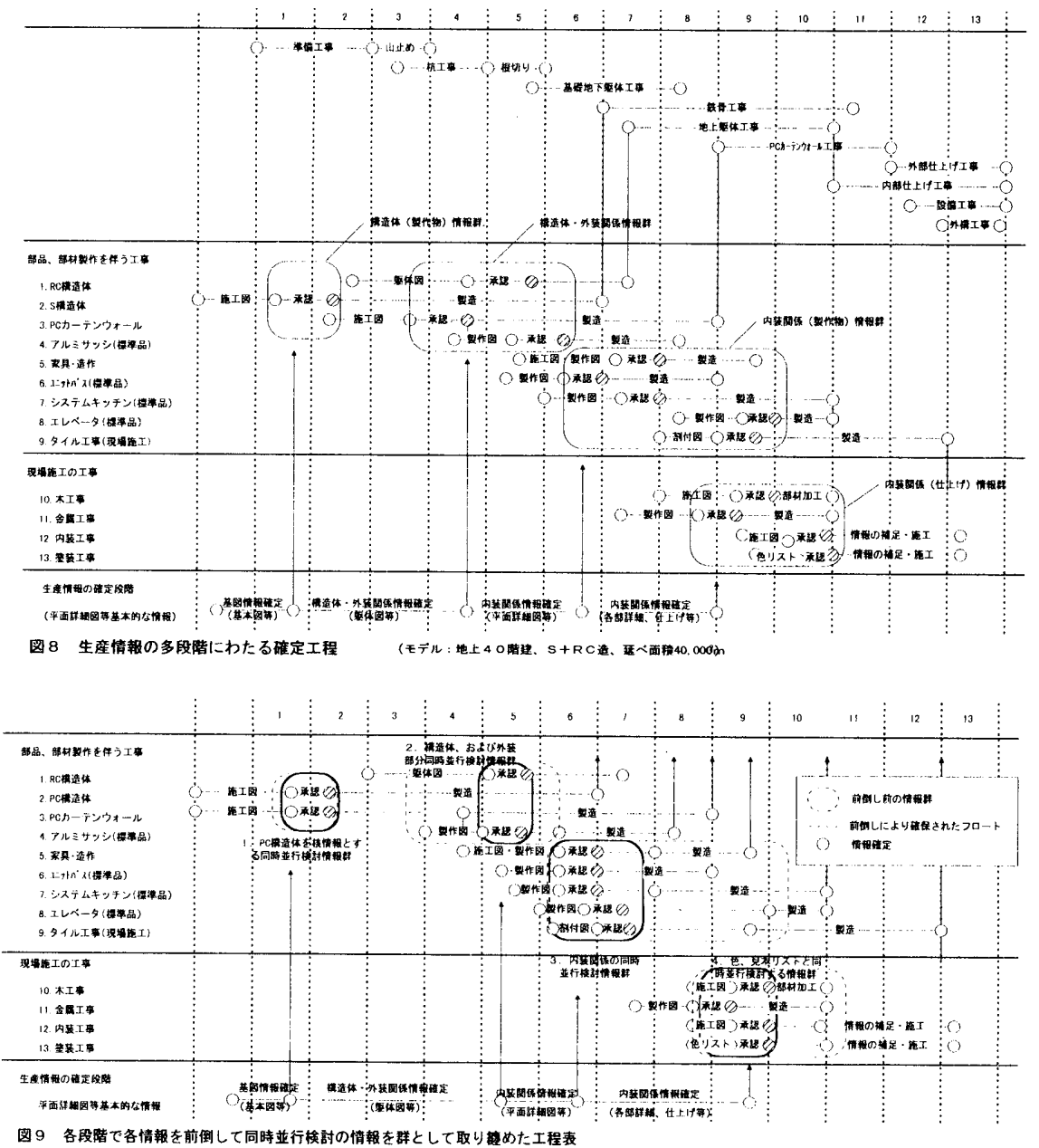


\section{GAを利用した計画的早期確定工程の生成}

GA（Genetic Algorithms:遺伝的アルゴリズム）は自然界における 生物の進化過程を応用して、問題環境への適合度が高い解を発見し ていくものである。 ${ }^{3}{ }^{4}$ ). 本論文においては、個々の作業の固まり を繋ぎあわせたものを遺伝子 1 個体ととらえ、これらの個体群に対 する遺伝子の組み替えや突然変異を利用して、より最適な工程（作 業に対する開始日および日数の組み合わせ）を生成する。

\section{1 GA分析の前提}

\section{1) GA分析の目的}

本論文では、当該プロジェクトに最適なバランスと思われる前倒 し確定の程度を求めるため、GAによる分析を試みる。プロジェク 卜の特徵、設計者や発注者の傾向を、計画的早期確定を行う際の制 約条件とした上で、可能な限り前倒しに向かうよう評価関数を設定 し、最適解の集合を求めようとするものである。

2）GAによる計画的早期確定の前提

a . 評価対象モデル

・評価対象の項目は図 8 に示す 13 の生産情報作業とする。

- 生産情報確定工程の前後関係は前出の図 1 に示した ISM および DEMATEL 分析による。このモデルでは、一部図面名称が異な るが、検討対象となる内容の一致するもので考慮した。

・各生産情報作成に関する初期工程は、フロートおよび同時並行 検討を考慮した前項の工程表システムの処理Aから導かれる。

- 各生産情報確定作業の作業内訳（作図、検討・承認、製作）に 関するコスト情報、および各生産情報に対する制約条件（最遅 日付）は前項の新工程システムから導かれる。

b. GAシステムで入力すべき情報

・前倒し戦略（図6に示す、先行して確定すべき平面詳細系の図 面予定完成日）を指定する。これにより I SMの分析結果から 各作業の前倒し限界日付が求まるので、これを前倒しの制約条 件とする。

-同時並行検討作業（複数の作業の間で、検討・承認時期がラッ プ）を指定する。

・implicit フロート削减時の費用増および作業日数削減による費用 減の度合いを比率として定義するとともに、計画的早期確定に 対する各種の定性的な抵抗要因（設計者の検討続行志向や労務 制約など）をフロート日数の削減限界值（日数）として与える。

- GA処理に対する評価戦略（工期優先の評価を行うか費用優先 の評価を行うか）を指定する。

・各生産情報確定工程を前倒しすることによるメリットを費用減 の比率として与える。

\section{c. GA処理における評価尺度}

- 各生産情報確定作業は、作業内訳（作図、検討・承認、製作） ごとに explicit フロートと implicit フロートを持ち、各フロート は削減限界值（前倒しに対する抵抗要因の定量化）を持つため、 この日数の増減を計算する。

・個別の作業に対しては、各フロート日数が初期日数を上回らな いこと、作業全体に対しては、総作業日数が初期総作業日数を 上回らないことを評価尺度とする。

・個別の作業に対しては、各作業の開始日が前倒し限界および同 時並行の制約を超えないこと、また最早開始日と最遅終了日の
間に含まれるかどうかを評価尺度とする。

・評価された作業内訳の総日数と各フロートの削減日数によるコ ストの増減から作業ごとのコストを計算し、初期作業コストと の比較を行う。

- 作業全体に対して労務制約の山積み評価を行い、複数の作業が 同時並行で行なわれる際の労務のラップが限界を超えないこと を評価尺度とする。

・作業全体に対して、総コスト（作業ごとのコストの合計）が初期 総コストを上回らないことを評価尺度とする。

\section{2 GA分析における評価}

\section{1) 染色体の構成}

個体の染色体の表現については、ビット列 $\{0,1\}$ に基づく 2 進 数表現を用いる。この時、個々の染色体は、遺伝子配列を構成する 各作業の、作業開始日、作図日数、承認日数、および製作日数のビ ット表現で表わされる。その際、総遺伝子配列数を押さえるために、 各作業の内訳日数に関しては、作図・承認・製作それぞれの implicit フロート日数（短縮することにより費用が発生する）の削减限界か らの日数および explicit フロート日数（短縮しても費用が発生しな い。逆に短縮することにより作業日数を短くできるため、費用が减 少する可能性がある。）の削减限界からの日数で遺伝子配列を作成 する。つまり、implicit フロート日数が 10 日間であり、労務状況など からその削減限界が 6 日（4 日間は短縮可能）の場合、遺伝子配列 として表現される日数は 4 日（000100）となる。したがって、1個 体の染色体のうち、各作業を表わす遺伝子配列は図 10 のように表 わされるため、各個体の染色体の表現は図 11 のようになる。しか しながら、本研究においては、GA処理の効率化を図るために、各 作業の開始日付を表現する遺伝子配列部分と作業日数を表現する遺 伝子配列を図 12 の様に分けて、初期遺伝子を作成している。 この時、

\section{- $\alpha_{\mathrm{i}, \mathrm{j}, \mathrm{l}} \geqq 0 \quad$ (i=個体数, $\mathrm{j}=1$ to $13, \mathrm{k}=1$ to $3, \mathrm{l}=1$ to 2 )}

- $\beta_{\mathrm{ij}} \geqq 0 \quad$ （i=個体数, $\mathrm{j}=1$ to 13 )

となり、各 $\alpha_{\text {ik, }}$ は 6 ビット、各 $\beta_{\mathrm{ij}}$ は 10 ビットで表現されるため、 1 つの作業を表わす配列は 46 ビット、1つの染色体配列のビット 数は598ビットとなる。

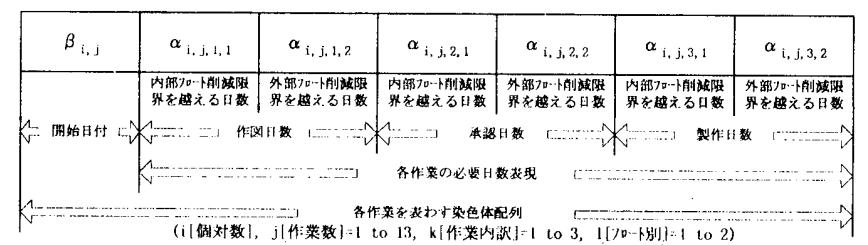

图 10 各作菜を表わす染色体配列

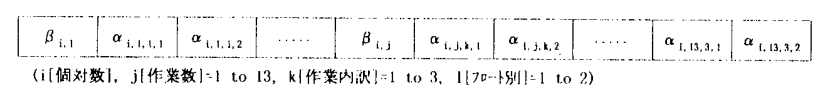

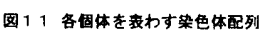

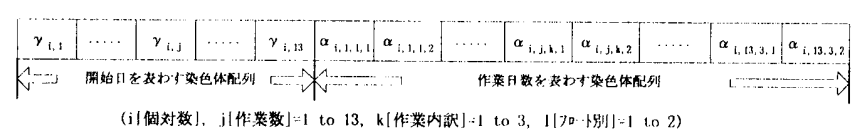
图 12 本研究で採用した策色体距列

\section{2）遺伝子の評価方法}

上記の各染色体に対して、作業日数の増減、作業開始日の前倒し 程度および各染色体に対する費用の増減が、以下の観点から評価さ 
れる。

·各内訳作業の日数（フロ-卜日数）が削減されているか。

·各作業の作業日数合計が削减されているか。

・各染色体の総作業日数が、初期染色体の総作業日数よりも削減さ れているか。

・implicit フロート日数削减による費用增と作業日数减による費用減の 結果はどうか。

・各作業の開始日が当該工事の最早開始日より早くないか。

・各作業の終了日が当該工事の竣工日より遅くないか。

・各作業の承認終了日が、その段階で先行確定する情報（平面詳細 系の図面）の確定よりも早くないか。

・同時並行検討作業間においては、承認期閒が重複するところまで 作業が前倒しされているか。

・複数作業が同時並行检討される部分において、担当者の労務山積 みによる作業集中度はどうか。

・前倒しによる費用減および、前倒しによる費用増の評価はどうか。 これらの評価項目を、それぞれ日数に関する評価関数、開始日付 に関する評価関数、および費用に関する評価関数として定義し、そ れぞれの評価関数にペナルティ值を加えたものの分数をとった上で、 それらの合計により各染色体の評価関数とした。

つまり、日数に関する評価においては、各 $\alpha_{i, j, 1}$ に対して

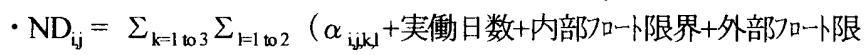
界)

が各作業ごとの作業日数となり、

$\cdot \mathrm{WD}_{\mathrm{i}}=\Sigma_{j-1013} \mathrm{ND}_{\mathrm{ij}}$

が染色体の作業日数の総和となる。これに対して、各 $\alpha_{\mathrm{ij}, \mathrm{k},}$ と $\alpha_{0 \mathrm{j}, \mathrm{k}, 1}$ （初期データ）とを比較し、日数が増加した作業に対してその差分 $\mathrm{P}_{\mathrm{i}}$ を作業日数の増加に対するペナルティ值とした。ここで、

$\cdot P_{i}=\Sigma_{j=1013} \Sigma_{k=103} \Sigma_{k=102}\left|\left(\alpha_{i j, k 1}-\alpha_{0, j k 1}\right)\right|$

で与えられる。

また、開始日付に関しては、各内訳作業の開始日を

- $\theta_{\mathrm{i}, \mathrm{i}}=\beta_{\mathrm{i}, 1}$ (各作業の開始日)

- $\theta_{i, 2,2}=\beta_{i, j}+$ 作図日数 （承認作業の開始日）

- $\theta_{i, j}=\theta_{i j, 2}+$ 承認日数 (製作作業の開始日)

- $\theta_{\mathrm{i}, 4}=\beta_{\mathrm{ij}, 1}$ 作業日数 (各作業の終了日)

とすると、各染色体の作業日数忙（作業の最遅終了日一作業の最早 開始日)、つまり

- $\mathrm{TD}_{\mathrm{i}}=\mathrm{MAX}_{\mathrm{j}-1613} \theta_{i, 4}-\mathrm{MIN}_{\mathrm{j}-1613} \theta_{i, \mathrm{i},}$

で求められる。これに対して、日数評価と同様にペナルティ值 $\mathrm{Q}_{\mathrm{i}}$ を考えると、この場合のペナルティ值 $\mathrm{Q}_{\mathrm{i}}$ は、

・各作業の開始日 $\theta_{\mathrm{i}, \mathrm{j}, \mathrm{k}}$ が I SM分析から導かれた前倒し限界を超 えていないか。

・各作業の終了日 $\theta_{i, j, 4}$ が入力された最遅終了日を超えていないか。

・ユーザーが指定した同時並行検討作業に対し、

$\theta_{i, j, 2} \leqq \theta_{i, j+1,2} \leqq \theta_{i, j, 3}$ または $\theta_{i, i, 2,} \leqq \theta_{i, j+1,3} \leqq \theta_{i, j, 3} \quad(1 \leqq j \leqq$

12）を満足しているかどうか。

などによって与えられる。

したがって、作業日数および開始日付汇関する評価関数は、前述の 各作業日数の総和、染色体の作業日数、およびそれらに対するぺナ ルティ值の和の分数として以下のように定義した。
- $\mathrm{EVl}_{\mathrm{i}}=1 /\left(\mathrm{WD}_{\mathrm{i}}+\mathrm{P}_{\mathrm{i}}+\mathrm{TD}_{\mathrm{i}}+\mathrm{Q}_{\mathrm{i}}\right)$

次にコストに関しては、各作業に対してコスト $\gamma_{\mathrm{j}, \mathrm{k}, 1}$ が以下のよ うに定義される。

- $\gamma_{\mathrm{j}, \mathrm{k} \mid} \geqq 0 \quad(\mathrm{j}=1$ to $13, \mathrm{k}=1$ to $3, \mathrm{l}=1$ to 3$)$

- $\gamma_{j \times 1}$ は必す固定（実稼動日数に対する費用は常に固定とする)

- $\gamma_{\mathrm{j}, 2,2}$ は内部》听短縮に伴亏費用增率

- $\gamma_{j k, 3}$ は外部叶短縮（または作業日数削喊）に伴う費用減率

したがって、各作業に対する費用は初期デー夕に対する「初期コス 卜十内部フロート日数削堿によるコスト増一作業日数减によるコス

卜減」によって評価される。つまり染色体の作業コストは

- $\mathrm{WC}_{\mathrm{i}}=\Sigma_{\mathrm{j}=1 \mathrm{\omega} 13}\left[\left(\gamma_{\mathrm{j}, \mathrm{k},} *\left\{\left(\alpha_{\mathrm{j}, 02}-\alpha_{\mathrm{j}, \mathrm{k}, 2}\right) * \gamma_{\mathrm{j}, 2,2}-\left(\alpha_{\mathrm{j}, 0,3}-\alpha_{\mathrm{j}, 3,3}\right) *\right.\right.\right.$ $\left.\left.\gamma_{\mathrm{jkk}, 3}\right\}\right]$

となる。ここで、 $\alpha_{i, 0,2}$ および $\alpha_{i 0,3}$ は、初期状態における各作業の 内部听および外部叶数とする。一方、作業の前倒しによるコ ストの増堿については、

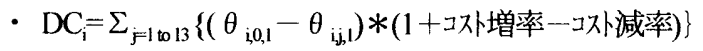

となるため、この $2 つ の$ 作業コストの和の分数をとり、以下のよう にコストに関する評価関数を定義した。

$\cdot \mathrm{EV}_{\mathrm{i}}=1 /\left(\mathrm{WC}_{\mathrm{i}}+\mathrm{DC}_{\mathrm{i}}\right)$

したがって、前述の作業日数と開始日付に対する評価值との和

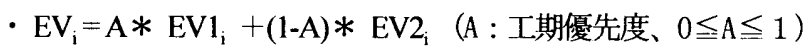

を、個々の染色体に対する選択確率とすることができる。

\section{3）遺伝子の操作}

染色体の選択については、各個体の選択確率の割合から個体を選 択するルーレット選択を用いる。ま た、遺伝子の交叉については、開始 日の染色体と作業日数の染色体は別 に扱い、それぞれのなかで交差させ る変則的な 1 点交叉とした。本シス テムでは収斂する世代数が最小にな るように、交差確率は、0.5 から 1.0 の間で試行し、0.6とした。同様に、 突然变異率は 0.002 から 0.01 の間で 試行し、0.005 とした。その結果、 世代数は収斂する最小限の世代とし て 200 とした。遺伝子操作のプロ セスを図 13 に示す。

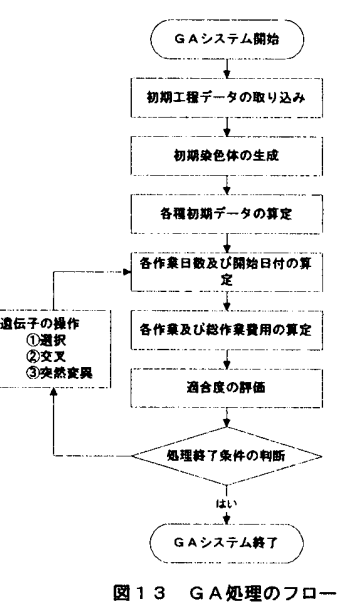

4）GAによる最適解集合の探索

GAの処理は、以下のような条件で害行し、作業日数、開始日付 の評価を総合すると、図 9 で想定したような結果を得た。

- 作業数

13 作業

・各染色体のビット数

598 ビット

- 初期個体数

- 交叉確率

50 個体

・突然変異確率

0. 6

- 世代数

0.05

200 世代

上記の条件により GA処理を行った結果、explicit フロートおよ び implicit フロートの削减による日数短縮のコスト削减効果と、 implicit フロート削减に伴うコスト増加を評価し、総作業日数を初 期日数から $5 \%$ 程度、削减寸ることができた。さらに、前倒し限界 
および同時並行検討の制約にそった作業開始日の移動により、全体 作業工期を初期日数から $20 \%$ 程度、削減することができた。

\section{5）残された課題}

生産情報の計画的早期確定への今回のGA分析は、まず段階内で の前倒しへの適用可能性について検討するために、各段階の生産情 報群の前倒しに大きく影響寸る基本的な情報（平面詳細図など）の 確定時期を予め入力し、その段階の範囲内で前倒しに向から傾向を 確かめたものである。この平面詳細図などの情報確定がプロジェク トの状況や、現場の規模、工事長の経験などに左右されるため、工 事長による入力という形態を採用したものである。したがって、こ こではより大きな効果が期待される 2.2 4）b 項で述べた複数 の段階の情報をまとめて前倒しする方法の適用可能性の検討は行つ ていない。

また、評価項目のうち、生産情報確定を前倒しする際の抵抗要因 の一つである、複数作業の集中に対寸る担当者の作業能力の評価(山 積み評価）からの制約を反映していない。これは、今回の段階内の 前倒しにおいては予め入力する基本的な情報の確定時期がその段階 生産情報群に対寸る前倒しの限界となり、山積み評価を行うメリッ トがあまりないと考えられるためである。

しかしながら、各段階を先導する基本的な情報の確定時期も前倒 しの対象となるものであり、その結果として、生産情報確定工程の 大幅な前倒しが期待されるものである。今後は、そのために発生す る複数の作業の集中に起因守る制約条件による評価も組み込、再度 GA処理を行い、自在に計画的早期確定を組み込むことのできる生 産情報確定工程の適用可能性について分析を続ける予定である。

\section{6. 生産情報工程表の活用により期待される効果}

本論文で提案した新しい生産情報確定工程の活用、および $\mathrm{GA}$ による最適解探索による計画的早期確定の効果を吟味する。

\section{1 新しい生産情報確定工程の活用による効果}

\section{1）生産情報確定期限の合意への活用}

提案するシステムで作成した生産情報確定工程を工事着工時に発 注者、設計者に提示し、設計内容の確定期限の打ち合わせに活用寸 る。また、 explicit フロートを活用して、特定の事項に関しては確 定時期を限界まで遅らせるなど、不満の残らない形での合意が可能 となる。

\section{2）生産情報の同時並行検討の支援}

各段階ごとに、生産情報の検討・承認の期間を重複させることに より、より幅の広い検討が可能で、検討の落ちを防止し、その後の 変更などの手戻りの計画的防止に役立つ。

\section{2 生産情報の計画的早期確定支援システムの活用}

\section{1）計画的早期確定によって得られる利益}

計画的早期確定により予想される利益は、すでに3.1 項の動機 で述べたとおりであり、作業所長の最大関心事である、コス下抑制 を、発注者や設計者の合意の下で合理的に可能にするものであり、 下記の 3 点に要約される。

・工事コスト、生産情報確定コストの合理的抑制

・同時並行検討を伴うため、生産情報の確定のための手間の削減 と内容の整合性の向上

・早期確定による工期の安定と不測の遅延などへの余裕ある対応

\section{2）GA による最適解の探索手法による効果}

建築プロジェクトは内容、工期、工事費ともにそれぞれ異なり一 般的に条件の標準化はできない。ここで提案した方法によれば、個 別のプロジェクトごとの特徴を作業所長の判断により入力し、得ら れた解を評価し、その中から、その現場に最適の案を選ぶ事が可能 な最適解近傍のプロジェクト特有の解を見つけることができる。

\section{7. まとめ}

生産情報の作成から確定に至る構造を明らかにし、最終的に、 発注者、設計者と協㗢し、お互いに満足を得ながら、計画的に、か つ早期に生産情報を確定していく、生産担当者にとっての戦略的な 生産情報確定工程システムを構築した。その結果をモデルプロジェ クトに適用し、本システムの妥当性と有効性を確認した。 今後の課題は以下のとおりである。

（1）GA分析で残された課題である、(1)複数の情報群をまとめて 前倒しすることへの適用可能性、(2)重複作業の集中による工 程能力の制約による評価の導入(3)突然変異、交叉率などのパ ラメータの設定を実務に照らして妥当なものにすること、な どについて、引き続き研究を行う。

（2）現場や工場の実生産工程と連携した生産情報確定工程システ 厶の構築を行う。

（3）各プロジェクトごとに妥当な定量化が行えるように、前倒し の手間や費用と得られる効果については、実例デ一夕を積み 重ねていきたい。

\section{謝辞}

本論文作成にあたり、清水建設の多くの作業所長の方から示唆をいただい た。特に高岡敏明工事長からは前倒し確定による実例をお示しいただくとと もに、本論構成上重要な助言をいただいた。和泉研究室の林康裕氏にはGA の使用にあたって多くの示唆をいただいた。さらに、京都大学長岡弘明教授 からは論文全体の構成、GA 手法について示唆をいただいたここに心から 謝意を表します。

注

注1）本論文では生産を担当する主 体を右記の上うな階層構成で 考える。

注2）GAでいう最適解とは、必ず しも最善の策を意味せ才゙、次善の策尾も含む概念である

\section{参考文献}

1）峰政克義、伊藤健司、古阪秀三、建築プロジェクトにお忊る生産情報 の確定過程、日本建筑学会計画系論文集、No502, p187-194, 1997, 12

2）峰政克義、服部克洋、坂本正史、古阪秀三、建築プロジェクトにおけ る生産情報の共有と整合のしくみ、日本建築学会計画系論文集、No504、 p 179-186, 1998, 2

3）長岡弘明、古阪秀三、山崎雅裕、金多隆、李永稿、岡本啓照、建築工 事における労務平淮化への遺伝的アルゴリズムの適用、日本建築学会 計画系論文集、No491，p 183-187，1997，1

4）李永稿、長岡弘明、古阪秀三、山崎雅裕、金多隆、労務コス卜に基づ く建築工事の労務資源配分最適化、日本建築学会計画系論文集、No504, p 187-194, 1998, 2

(1998年2月 9 日原稿受理，1998年8月21日採时法分: 